Ročník XVII (2015), Číslo 2, s. 234-236/ Volume XVII (2015), Issue 2, pp. 234-236

(c) Mezinárodní politologický ústav / International Institute of Political Science

DOI: $10.5817 / C E P S R .2015 .2 .234$

\title{
Lukáš Linek a Pat Lyons: Dočasná stabilita? Volební podpora politických stran v České republice v letech 1990-2010
}

Praha: Sociologické nakladatelství a Sociologický ústav AV ČR, v.v.i., 2015. 222 s., ISBN 978-80-7419-160-2

DAN RYŠAVÝ ${ }^{1}$

Kdo by chtěl po parlamentních volbách 2013 diskutovat o otázce v titulu práce Lukáše Linka a Pata Lyonse? Není vše dostatečně jasné? V době předcházející parlamentním volbám 2010 ještě mohla být řeč o „křehké stabilitěc“ (Deegan-Krause a Haugton 2010). Proč se ale po „politickém zemětřeseni““ (Hanley 2011), které s sebou prinesly, ještě vracet k otázce stability jinak než jako k otázce řečnické? Pro význam recenzované práce je klíčové posoudit, zda renomovaní autoři tentokrát neprrišli tak říkajíc „s křížkem po funuse“. Důkladnější čtení knihy nabízí opatrnou odpověd’: Nezdá se.

Knihu o volební podpoře politických stran v České republice v letech 1990 2010 jsem poprvé otevíral jako svého druhu referenční publikaci, z potřeby kontextualizovat své vlastní úvahy. Texty obou autorů, at' už je publikují jako jednotlivci nebo společně, přinášejí pravidelně kus poctivé práce a nezůstávají bez ohlasů. Nejinak je tomu v př́padě recenzované knihy vydané Sociologickým nakladatelstvím v koedici s pracovištěm autorů, Sociologickým ústavem AV ČR, v.v.i. K silným stránkám práce patř́ jasná konceptuální struktura, bohatá inspirace zahraniční literaturou a analytické postupy, jež se v domácí politologické produkci spíše zabydlují, než že by ji dlouhodobě charakterizovaly. Kontrolní roli sehrávají kombinace různých typů analýz, což ve výsledku posiluje přesvědčivost vyvozovaných závěrů.

Volební rozhodování podle autorů významně ovlivňují tři konfliktní linie sociální třída, náboženství a generační prúslušnost. Zatímco sociální třída staví proti sobě levicové a pravicové strany, druhé dvě linie jsou asymetrické, nebot’ ze stranického systému vydělují vždy jen jednu (významnou) politickou stranu, a to

1 Katedra sociologie, andragogiky a kulturní antropologie, Filozofická fakulta, Univerzita Palackého, Olomouc / Department of Sociology, Andragogy and Cultural Anthropology, Faculty of Arts, Palacký University, Olomouc, Czech Republic. E-mail: dan.rysavy@upol.cz 
KDU-ČSL v př́padě náboženství a KSČM v případě generační linie. Dalším faktorem, kterému věnují Linek a Lyons při vysvětlování chování voličů pozornost, je levo-pravá hodnotová orientace. Konečně předpokládají, že model volby strany založený na konfliktních liniích a levo-pravé orientaci mnohem lépe vysvětluje hlasování osob, které se s některou ze stran identifikují, než jedinců bez této psychologické vazby. Posledně zmíněných není málo a přibývá jich. Už z načrtnutého modelu je patrné, že Linek a Lyons dávají přednost časově náročnější, zato teoreticky ukotvené analýze před rychlými komentáři momentálního vývoje voličské podpory. Jsou si přitom vědomi, že tím jdou tak trochu proti převažující poptávce: „Člověk by si totiž pod náporem současných výzkumů kampaní a volebního marketingu skoro ani neuvědomil, že existuje něco jako konfliktní linie, ideologie a stranictví. Je to mimo jiné i proto, že mediální interpretace voleb konzistentně tyto důležité dlouhodobé faktory nereflektuji“" (s. 173). Hodnotu textu přes jeho zdánlivou neaktuálnost dokládají otázky a perspektivy, jež čtení vyvolává. Důkladnému čtenáři se jich nabízí nepřeberně, za všechny zde zmíním dvě.

Za prvé, prrinejmenším od konce 90. let minulého století je i v České republice zřejmé, že spolu sociální třídy a levo-pravá orientace úzce souvisí. Linek a Lyons však připojují netriviální zjištění - význam třídního hlasování pro volební výsledky v čase vzrostl, u levo-pravé orientace došlo ke stagnaci či dokonce k poklesu. Co to vypovídá o dnešku? Např́klad to, že z klesajících volebních zisků tradičně nejsilnějších stran levice a pravice, kterých jsme byli svědky v posledních dvou parlamentních volbách, nelze automaticky vyvozovat, že na sociálním postavení elektorátu nezáleží.

Za druhé, při zpětném pohledu se větší váha nezř́idka připisuje volbám, po nichž došlo ke strí́dání vlád levice a pravice. Oproti letům 1998 a 2006 však Linek a Lyons zdůrazňují význam parlamentních voleb 2002 a 2010. V roce 2002 došlo $\mathrm{k}$ významnému poklesu ve stranické identifikaci a náklonnosti voličů $\mathrm{k}$ některé ze stran, o osm let později byl zaznamenán podstatný nárůst volatility a s tím i pokles podílu voličů stabilně hlasujících pro stejnou stranu. Škoda jen, že ve volební studii zabývající se rokem 1998 nebyla sledována stranická identifikace respondentů.

Dva vybrané závěry by měly zajímat mj. ty, kteří volají po změně volebního systému jako léku na jiný přetrvávající rys českého politického systému, totiž opakující se vytváření nestabilních vlád. Změna pravidel hry by totiž nemusela přinést očekávaný výsledek. Na jedné straně by posunu ke kýženému výsledku mohly bránit ustálené konfliktní linie, na straně druhé lze jen stěží předjímat efekt takové změny pro chování voličů neidentifikovaných s konkrétní stranou. Ostatně nejistota předvídání výsledků voleb je rysem, kterým se Česká republika nijak nevymyká z širšího a nejen evropského kontextu.

Nakonec připojuji několik formálních prripomínek. Shrnutí na konci jednotlivých kapitol umožňuje číst knihu nejen jako celek, ale také po kapitolách. 
Čtenáři, kteří budou postupovat „od A do Zet“", se však místy těžko ubrání dojmu př́liš častého opakování. Orientaci knihy by pak napomohlo, kdyby stránkování uvedené v obsahu odpovídalo realitě. Rozdíl je patrný už na konci první kapitoly a u osmé činí čtyři strany. Naopak př́loha 2 se v obsahu jeví útleji, než je tomu ve skutečnosti. Z vlastní zkušenosti vím, že vychytat všechna nedopatření při korekturách knihy je téměř nadlidský úkol. Př́kladem je graf 4.4, u něhož je v poznámce vysvětleno omezení dolní hranice směrodatné odchylky u KSČM nejnižší hodnotou na levo-pravé stupnici (0), ale to samé není aplikováno na druhý konec škály. Interval uvedený u ODS tak přesahuje maximální hodnotu škály (10) a měŕítko je vedeno až do hodnoty 12.

S každými dalšími volbami začne pomalu usedat prach na výsledky těch předchozích. Stojí však za to, když se někdejší rozdělení voličské prrízně nestává pouze součástí snadno vyjádřitelných trendů, ale předmětem důkladné analýzy opírající se o jevy trvalejší povahy. Nezřídka je nelze zkoumat prímo a úsilím hraničícím s marností by byla snaha představit jejich úplný model. Cesta, pro kterou se rozhodl Lukáš Linek a Pat Lyons, vyzývá ke kritickému následování.

\section{Literatura:}

Deegan-Krause, Kevin a Tim Haugton (2010): „A Fragile Stability: The Institutional Roots of Low Party System Volatility in the Czech Republic, 1990-2009.“ Politologický casopis 17(3): 227-241.

Hanley, Seán (2011): „Dynamika utváření nových stran v České republice v letech 19962010: hledání možných příčin politického zemětřesení." Sociologický časopis 47(1): 115136. 